\title{
Differences in the proportions of branched-chain fatty acids in subcutaneous triacylglycerols of barley-fed ruminants
}

\author{
BY W. R. H. DUNCAN AND G. A. GARTON \\ Rowett Research Institute, Bucksburn, Aberdeen AB2 $9 S B$ \\ (Received 25 July 1977 -Accepted 25 November 1977)
}

\begin{abstract}
1. The fatty acids of the triacylglycerols of subcutaneous adipose tissue of cattle, sheep, goats and red deer (Cervus elaphus) which consumed either herbage or a barley-rich diet were analysed for their content of branched-chain components.

2. Whereas the consumption of the barley-rich diet by sheep and goats was associated with the occurrence of relatively high proportions of branched-chain fatty acids, it was not in cattle and red deer.
\end{abstract}

Previous studies in this laboratory (Garton, Hovell \& Duncan, 1972; Duncan, Lough, Garton \& Brooks, 1974) showed that, when sheep were fed on carbohydrate-rich (cereal) diets, the ruminal production of enhanced amounts of propionate (Ørskov, Fraser \& Gordon I974) was associated with the occurrence of unusually high proportions of odd-numbered, straight-chain fatty acids and considerable proportions of saturated, methyl-branched fatty acids in the depot triacylglycerols. Propionyl-CoA acts as the direct precursor of oddnumbered acids (cf. Horning, Martin, Karmen \& Vagelos, I96I) and indirectly, following its carboxylation to methylmalonyl-CoA, as the source of the methyl substituents of the branched-chain fatty acids (BCFA) (Scaife \& Garton, 1975).

The present study was undertaken to find out whether other ruminant species, namely the goat, ox (Bos taurus) and red deer (Cervus elaphus), responded similarly to the sheep when they were fed on diets rich in readily-fermentable carbohydrate in the form of barley. Some of the results pertaining to the goat have been published in a preliminary communication (Duncan, Ørskov \& Garton, 1976).

\section{EXPERIMENTAL}

\section{Source of adipose tissue}

Pieces of subcutaneous adipose tissue (each approximately $20 \mathrm{~g}$ ) were obtained at slaughter, from six young male goats, six young steers and one young red deer stag, all of which were kept in pens and fed on a pelleted diet containing barley $(900 \mathrm{~g} / \mathrm{kg})$, together with a mixture $(\mathrm{I} 00 \mathrm{~g} / \mathrm{kg}$ ) of white fish meal, minerals and vitamins. The goats and the red deer were given this diet for 5-6 months before slaughter and the steers received the diet for 9-10 months. For comparative purposes similar samples of subcutaneous adipose tissue were taken from three semi-feral goats (two males and one female) killed in south-west Scotland, from three feral red deer (hinds) which were shot in north-east Scotland, and from six steers which had been fed on grass for approximately Io months; the food of the semi-feral goats presumably consisted mostly of grasses, whilst that of the feral red deer was heather (Calluna vulgaris) and grasses, as judged from their rumen contents. In addition, subcutaneous adipose tissue was obtained, at slaughter, from nine r-year-old sheep, six of which had been fed from weaning on the high-barley diet referred to previously (i.e. similar to that used previously in the experiments of Garton et al. 1972) and three of which had been fed on grass alone since weaning. 


\section{Extraction and analysis of triacylglycerols}

The triacylglycerols were extracted from each sample of adipose tissue with acetone as described by Garton et al. (1972); thin-layer chromatography (Garton \& Duncan, 1964) showed that no other lipid was present in the extracts in detectable amounts. The triacylglycerols were saponified under reflux with $0.5 \mathrm{M}$-potassium hydroxide in ethanol and the recovered fatty acids were converted to their methyl esters by refluxing with excess methanol containing sulphuric acid ( $\mathrm{I}: \mathrm{IOO}, \mathrm{w} / \mathrm{w}$ ). The methyl esters derived from individual animals were then pooled, according to species and diet, to give composite samples for further detailed analysis. To facilitate subsequent fractionation, a weighed amount of esters was then hydrogenated or the unsaturated components were removed by treatment with mercuric acetate (Jantzen \& Andreas, I958). The resulting saturated esters were then fractionated as follows.

\section{Fractionation of saturated fatty acid esters}

A weighed portion of the saturated esters was treated with urea according to the method of Ackman \& Hooper ( 1968 ), by means of which a considerable proportion of the straightchain components is retained in the form of crystalline urea adducts and the esters of the BCFA remain in solution. Fach of the two resulting fractions of methyl esters was weighed. This 'enrichment' procedure provided the material for analysis of the component esters of the BCFA by gas-liquid chromatography.

\section{Gas-liquid chromatography}

The esters were chromatographed on a wall-coated, open-tubular stainless-steel column, $100 \mathrm{~m}$ in length and $0.25 \mathrm{~mm}$ i.d., coated with polymerized butanediol succinate. The column was operated isothermally in a chromatograph with a flame-ionization detector (Series I04; Pye Unicam, Cambridge) fitted with a sample inlet splitter giving a ratio of $97: 3$. The detector-oven temperature was $250^{\circ}$ and that of the injection-port heater was $260^{\circ}$; the column was maintained at $162^{\circ}$ and argon was used as carrier gas at $\mathrm{I} \mathrm{ml} / \mathrm{min}$. Chromatographic peaks were identified on the basis of the accordance of their equivalent chain-length values with those of the methyl esters of authentic iso- and anteiso-fatty acids and with those of other BCFA which had previously been identified in this laboratory (Duncan et al. 1974) by mass spectrometry when methyl esters of BCFA from barley-fed sheep were chromatographed under conditions similar to those used in the present study.

\section{RESULTS AND DISCUSSION}

As Table I shows, the feeding of a barley-rich diet to goats was associated, as it is in sheep (see also Garton et al. 1972), with the presence of considerable proportions of BCFA in the subcutaneous triacylglycerols; cattle, on the other hand, did not respond in a comparable manner to such a diet and the proportions of BCFA were of a similar low order to those present in the subcutaneous triacylglycerols of grass-fed cattle. Though with respect to the red deer, it was possible to analyse only one sample of subcutaneous adipose tissue from a barley-fed animal, it appeared that this species resembled cattle in that abnormal proportions of BCFA were not present.

Until recently the only BCFA which had been shown to occur in the adipose tissue fatty acids of ruminants were very small percentages $(\mathrm{I}-2 \%)$ of members of the iso- and anteisoseries, together with traces of polymethyl-substituted acids which originate from the metabolism of the phytol moiety of dietary chlorophyll (see Lough, 1973). The iso- and anteiso-acids (the general formulas of which are indicated later) results largely from the 
Table I. Relative percentages of branched-chain fatty acids $(B C F A)$ in the fatty acids of the subcutaneous triacylglycerols of four species of ruminants

\begin{tabular}{|c|c|c|c|c|c|c|c|}
\hline \multirow[b]{3}{*}{ Species } & \multirow[b]{3}{*}{$\begin{array}{l}\text { No. of } \\
\text { animals } \dagger\end{array}$} & \multirow[b]{3}{*}{ Diet } & \multicolumn{5}{|c|}{ BCFA ( $\%$ total weight of fatty acids) } \\
\hline & & & \multirow[b]{2}{*}{ Total } & \multicolumn{3}{|c|}{ Monomethyl } & \multirow[b]{2}{*}{$\begin{array}{l}\text { Di- and } \\
\text { polymethyl }\end{array}$} \\
\hline & & & & Iso & Anteiso & Others* & \\
\hline Sheep & $\begin{array}{l}3 \\
6\end{array}$ & $\begin{array}{l}\text { Grass } \\
\text { Barley }\end{array}$ & $\begin{array}{r}2 \cdot 76 \\
15 \cdot 38\end{array}$ & $\begin{array}{l}0.67 \\
1.01\end{array}$ & $\begin{array}{l}0.93 \\
I .57\end{array}$ & $\begin{array}{l}0.94 \\
9.34\end{array}$ & $\begin{array}{l}0.22 \\
3.46\end{array}$ \\
\hline Goat & $\begin{array}{l}3 \\
6\end{array}$ & $\begin{array}{l}\text { ? Grass } \\
\text { Barley }\end{array}$ & $\begin{array}{r}5 \cdot 13 \\
11 \cdot 30\end{array}$ & $\begin{array}{l}I \cdot 78 \\
I \cdot 50\end{array}$ & $\begin{array}{l}2.64 \\
0.93\end{array}$ & $\begin{array}{l}0.11 \\
5.98\end{array}$ & $\begin{array}{l}0.60 \\
2.89\end{array}$ \\
\hline Cattle & $\begin{array}{l}3 \\
6\end{array}$ & $\begin{array}{l}\text { Grass } \\
\text { Barley }\end{array}$ & $\begin{array}{l}2 \cdot 00 \\
1 \cdot 48\end{array}$ & $\begin{array}{l}0.92 \\
0.47\end{array}$ & $\begin{array}{l}0.97 \\
0.88\end{array}$ & $\begin{array}{l}0.10 \\
0.06\end{array}$ & $\begin{array}{l}0.01 \\
0.07\end{array}$ \\
\hline \multirow[t]{2}{*}{$\begin{array}{l}\text { Red deer } \\
\text { (Cervus elaphus) }\end{array}$} & 3 & $\begin{array}{l}\text { Heather (Calluna } \\
\text { vulgaris) and grass }\end{array}$ & $1 \cdot 89$ & 0.46 & $I \cdot 2 I$ & 0.04 & 0.18 \\
\hline & $\mathbf{I}$ & Barley & 0.97 & 0.21 & 0.63 & 0.11 & 0.02 \\
\hline
\end{tabular}

* Includes a number of acids with a methyl substituent on one of the carbon atoms between $\mathrm{C}_{3}$ (from the methyl end of the molecule) and the carboxyl end.

$\dagger$ No. of individual animals from which samples were obtained to provide fatty acids which were pooled for analysis.

digestion and assimilation of rumen bacterial lipids (Garton, 1964); for the most part the acids consist of methyl-substituted tetradecanoic (myristic) and hexadecanoic (palmitic)<smiles>CC(C)CCCCCC(=O)O</smiles>

iso-series (i.e. containing the isopropyl group)<smiles>CCC(C)CCC(=O)O</smiles>

anteiso-series (i.e. substituted on the antepenultimate $\mathrm{C}$ )

acids and $x$ is $I I, I 2$ or $I 3$ (iso-series) and Io or I2 (anteiso-series). These acids were identified in every preparation of BCFA which was analysed in the present study. Iso-acids are synthesized by rumen bacteria from the products of oxidative deamination of the branched-chain amino acids valine and leucine, and anteiso-acids are similarly synthesized from isoleucine (see El-Shazly, 1952; Lennarz, 1961).

Anteiso-acids, but not iso-acids, can also originate by another metabolic route, i.e. the utilization of methylmalonyl-CoA instead of malonyl-CoA for the first step in the chainlengthening of a fatty acid chain being synthesized from acetyl-CoA as the primer unit (Scaife \& Garton, 1975). Methylmalonyl-CoA can similarly substitute for malonyl-CoA in subsequent steps in chain-lengthening, thus giving rise to BCFA containing a single methyl substituent on any 'even-numbered' $C$ (i.e. numbering from the carboxyl- $C$ taken as I), regardless of whether acetyl-CoA or propionyl-CoA was the primer unit for synthesis; in addition, di- and trimethyl-substituted BCFA can be formed (Duncan et al. 1974; Scaife \& Garton, 1975). A wide variety of such acids was previously shown to be present in the adipose tissue triacylglycerols of barley-fed sheep (Garton et al. 1972) and, in the present work, these BCFA were found in relative abundance in the triacylglycerols of barley-fed goats as well as of barley-fed sheep, but not of barley-fed cattle and red deer (Table I). Extremely small proportions of some of the same BCFA were, however, present in the triacylglycerols not only of barley-fed cattle and goats but also of grass-fed sheep, goats, 


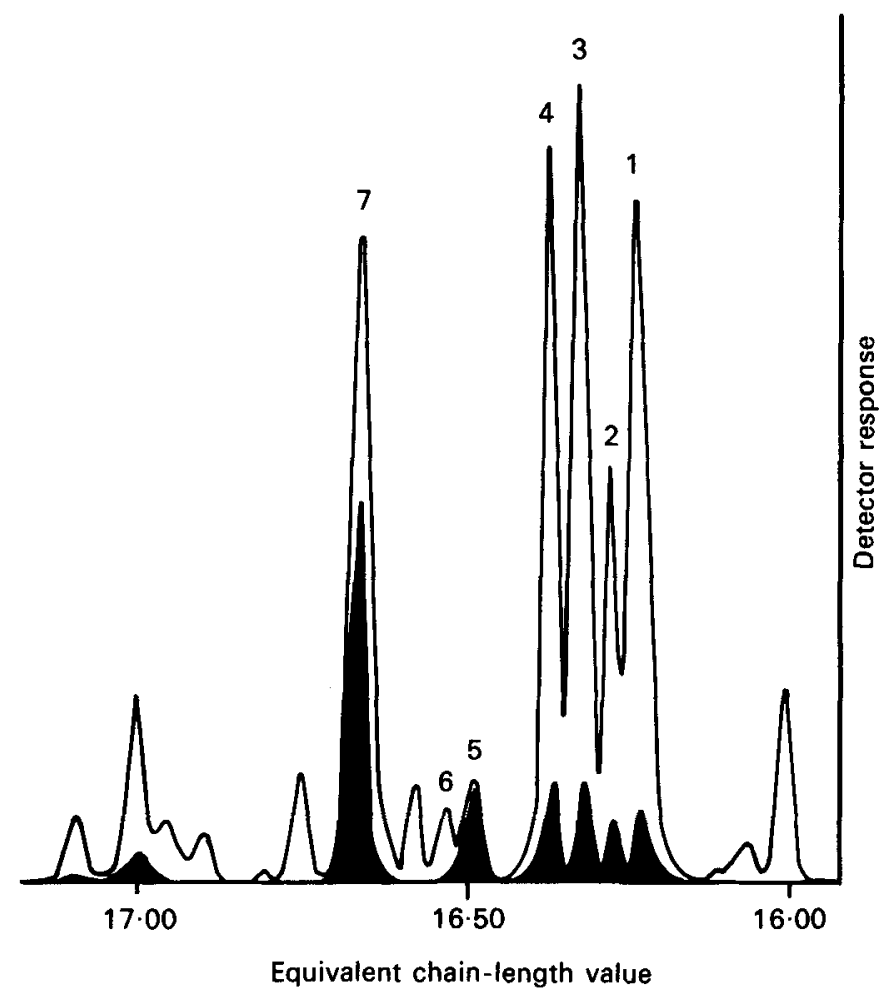

Fig. I. Portions of the gas-liquid chromatograms of the methyl esters of the branched-chain fatty acids prepared from the subcutaneous triacylglycerols of barley-fed sheep ( $\square$ ) and grass-fed sheep (w). Stainless-steel, open-tubular column (I00 $\mathrm{m} \times 0.25 \mathrm{~mm}$ i.d.) coated with polymerized butanediol succinate; operating temperature $162^{\circ}$, with argon as the carrier gas. The chromatograms are superimposed on a common scale with respect to the proportional contribution of the peaks to the total peak area of the total fatty acids of the triacylglycerols. Identities of methyl esters: (1) mixture of 6- and 8-methylhexadecanoate, (2) 10-methylhexadecanoate, (3) 4-methylhexadecanoate, (4) 12-methylhexadecanoate, (5) 15 -methylhexadecanoate (iso), (6) 4,8-dimethylhexadecanoate, (7) I4-methylhexadecanoate (anteiso).

cattle and red deer. Trace amounts of some of these BCFA have previously been found by other workers in the depot triacylglycerols of grass-fed sheep (Ackman, Hooper \& Hansen, 1972; Hansen \& Czochanska, I 976).

The difference between barley-fed and grass-fed sheep in terms of the number and order of abundance of BCFA is illustrated in Fig. $I$ in which the same sections of the two gasliquid chromatograms are superimposed on a common scale with respect to the proportional contribution of the peaks to the total peak area of the total fatty acids of the triacylglycerols. It can be seen that the number and proportions of BCFA were greater in the preparation from barley-fed sheep with the exception that the iso-acid, I5-methylhexadecanoic acid, was present in similar proportions in both BCFA preparations as might have been expected since methylmalonyl-CoA does not, as noted previously, take part in the biosynthesis of iso-acids. As is indicated in the legend to Fig. I, it was possible to assign identities to several BCFA in addition to the iso-acid and the anteiso-acid, 14-methylhexadecanoic acid; these BCFA included a number of positional isomers with 'mid-chain' methyl branches and the di-branched acid, 4,8-dimethylhexadecanoic acid.

In sheep (Ørskov et al. I974), cattle (Kay, Fell \& Boyne, 1969) and goats (E. R. Ørskov, 
personal communication) it has been demonstrated that ruminal fermentation of barley starch can lead to the production of considerable amounts of propionate. It thus appears that the interspecies differences in the response, in terms of BCFA production, to a diet rich in barley may be related to differences in the effectiveness with which the animals metabolize propionate and its carboxylation-product, methylmalonyl-CoA.

\section{REFERENCES}

Ackman, R. G. \& Hooper, S. N. (I968). Comp. Biochem. Physiol. 24, 549.

Ackman, R. G., Hooper, S. N. \& Hansen, R. P. (1972). Lipids 7, 683.

Duncan, W. R. H., Lough, A. K., Garton, G. A. \& Brooks, P. (1974). Lipids 9, 669.

Duncan, W. R. H., Ørskov, E. R. \& Garton, G. A. (1976). Proc. Nutr. Soc. 35, 89A.

El-Shazly, K. (1952). Biochem. J. 51, 647.

Garton, G. A. (1964). In Metabolism and Physiological Significance of Lipids, p. 335 [R. M. C. Dawson and D. N. Rhodes, editors]. London: Wiley.

Garton, G. A. \& Duncan, W. R. H. (1964). Biochem. J. 92, 472.

Garton, G. A., Hovell, F. D. DeB. \& Duncan, W. R. H. (1972). Br. J. Nutr. 28, 409.

Hansen, R. P. \& Czochanska, Z. (1976). N. Z. Jl Sci. 19, 413.

Horning, M. G., Martin, D. B., Karmen, A. \& Vagelos, P. R. (196I). J. biol. Chem. 236, 669.

Jantzen, E. \& Andreas, H. (1958). Angew. Chem. 70, 656.

Kay, M., Fell, B. F. \& Boyne, R. (1969), Res. vet. Sci, ro, 181.

Lennarz, W. J. (1961). Biochem. biophys. Res. Commun. 6, 112.

Lough, A. K. (1973). In Progress in the Chemistry of Fats and other Lipids, vol. 14, p. I [R. T. Holman, editor]. Oxford: Pergamon Press.

Ørskov, E. R., Fraser, C. \& Gordon, J. G. (I974). Br. J. Nutr. 32, 59

Scaife, J. R. \& Garton, G. A. (1975). Biochem. Soc. Trans. 3, IOI I. 